\title{
On the Hairs of the Tomentum and Ovary in Rhodo- dendron Falconeri, Hook. f., and Rhododendron Hodgsoni, Hook. f.
}

\author{
Bर̃
}

\section{ENID M. JESSON.}

With one Figure in the Text.

$A^{\mathrm{S}}$ the tomenta of the leaves of Rhododendron Falconeri, Hook. f., and A Rhododendron Hodgsoni, Hook. f. (both belonging to the section Eu-Rhododendron), were found to present a different appearance, they were anatomically examined during a critical study of the two species. Further, seeing that the indumentum of the ovary of $R$. Falconer $i$ was also found to exhibit considerable differences in its character and was variously described as 'hirsutissimum viscosum' and 'densely ferruginous woolly', the investigation was extended to that organ. The result of this investigation is embodied in the following paragraphs.

\section{LEAVES.}

The leaves of $R$. Falconeri are described by C. B. Clarke in Hook. f. Fl. Brit. Ind. as 'large, long-petioled, elliptic, ferruginous tomentose beneath, very coriaceous', and these, as well as those of the following species, are figured in Hook. f. Rhododendrons of the Sikkim Himalaya, tt. $\mathrm{xv}$ and $\mathrm{x}$ respectively. A leaf of intermediate age was selected for examination, about $18 \mathrm{~cm}$. long and $10 \mathrm{~cm}$. wide. The tomentum itself is particularly conspicuous, forming an orange-brown or cinnamon-coloured covering, soft and velvety in texture, thickest at the midrib and thinning out towards the margin. A portion of this tomentum was scraped off and mounted in glycerine jelly containing gentian violet. On examination it was seen to consist of hairs made up of a delicate network of cells in the form of a funnel, the uppermost cells of which elongate, forming branches or chains of thin-walled cells (Fig. $A$ ), the branches being composed of a single row of cells. Frequently individual cells become more or less inflated, approaching a more spherical outline, but as a rule they are ellipticovate. The hairs stand at right angles to the surface of the leaf, so that sections cut parallel to it reveal a number of hairs in transverse section, those

[Annals of Botany, Vo1. XXIX. No. CXVI. October, I9I5.] 
from the middle and lower part of the hair appearing as continuous rings of collapsed cells, the whole being devoid of contents.

In $R$. Hodgsoni the leaves are described by Clarke, 1.c., as 'longpetioled, narrowly obovate-oblong, cinnamomeous or whitish subtomentose beneath'. A medium-sized leaf is about $21 \mathrm{~cm}$. long by $8 \mathrm{~cm}$. broad, but in order to examine the tomentum a young leaf was selected. In this condition the tomentum is of a dull cinnamon colour, granular in appearance and conveying none of the velvety appearance of $R$. Falconeri. In older leaves the tomentum becomes thinner and more scattered, and the individual hairs much smaller, till in the oldest leaves it loses all granular appearance and merely looks like a brown skin. This is not the case in $R$. Falconeri, as the tomentum never loses its felt-like appearance, though in older leaves

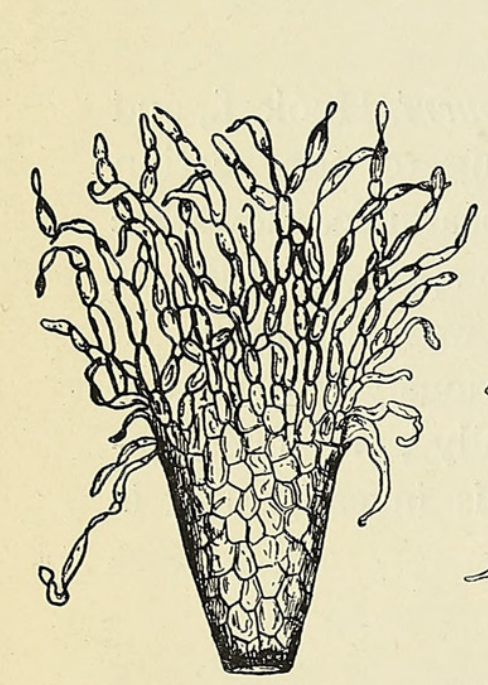

A

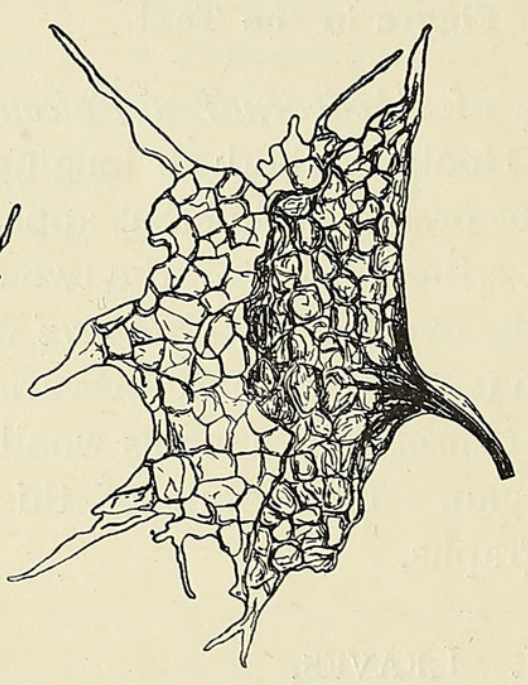

$B$

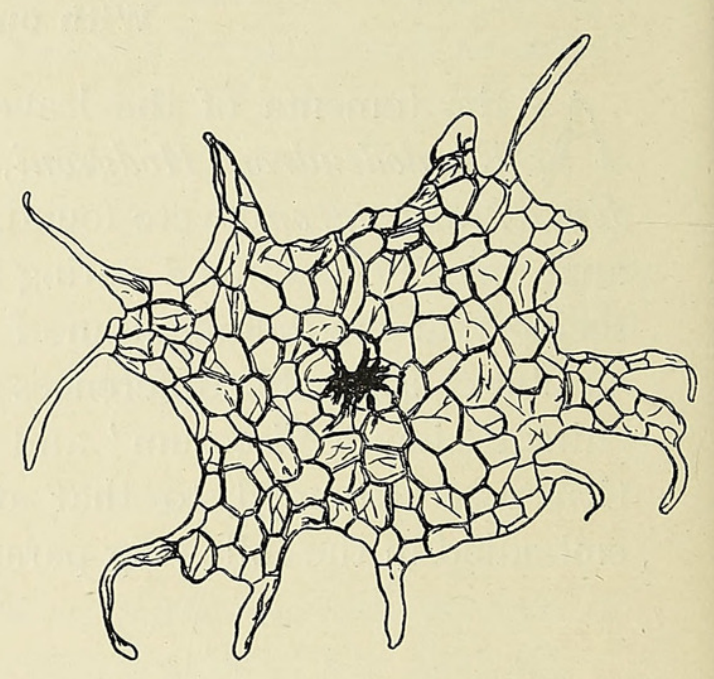

$C$

Hairs from the tomentum of Rhododendron Falconeri $(A)$ and $R$. Hodgsoni $(B$ and $C)$. All greatly magnified.

it may become somewhat blackish in colour. The hairs of R. Hodgsoni are peltate, and consist of a saucer-shaped mass of cells, having a stalk attached at the centre of the convex surface (Fig. B). Here also, the outermost cells are prolonged, but the arms are much shorter, more pointed, and are usually formed simply by the elongation of the outer cell, without further division, and are thus unicellular and not multicellular as in the previous case. Breitfeld ${ }^{1}$ describes a broom-shaped, shaggy hair from the leaves of several species of Rhododendron, including those of Rhododendron Falconeri. The writer has not been able to find any such hairs on the leaves, but the ovary possesses a very similar type, as will be seen below.

In considering the relation of these trichomes to the other types exhibited by the genus, the typical peltate form seems to be the simplest, and the form from which those now under consideration have sprung

1 Breitfeld : Der anatomische Ban der Blätter der Rhodendroideae, in Engler's Jahrb. ix (I 888), 3I9, Taf. vi, Figs. 3 and 6. 
by further differentiation. Such a primitive peltate hair would consist of a short, multiseriate stalk, the head being composed of an inner circular disc of small cells and an outer annular zone of large elongated cells. This type is of widespread occurrence and is figured by Breitfeld, 1.c., from Rhododendron Malayanum, Jack. The next stage in the development would seem to be that of Rhododendron Anthopogon, Don., where the stalk is longer and the outer zone curved upwards to form a cup, the inner cells, however, are still few in number; a figure of this hair may be seen in Solereder, Systematic Anatomy of the Dicotyledons (English edition), p. 485. From this it is easy to imagine the evolution of the type found in Rhododendron Hodgsoni by the extended development of the central disc, and of that in $R$. Falconeri by the upward growth of the main mass of cells, so as to form a funnel rather than a saucer-shaped structure-the stalk at the same time having become reduced $(R$. Hodgsoni) or suppressed $(R$. Falconeri).

\section{OVARIES.}

The ovary of $R$. Falconeri was originally described and figured by Sir Joseph Hooker, 1.c., tab. $\mathrm{x}$, as 'hirsutissimum viscosum', and the original drawing shows the ovary green and densely covered with short, stiff hairs, with what look like drops of a viscid matter adhering to them. There are no specimens at Kew which can be identified with certainty as being of this collecting on Tonglo. But from plants collected later in the same year (1848) in different localities, the ovary has been found to be not hirsute at all, but apparently glabrous and covered with a copious viscous substance. When examined, this covering was seen to be composed of a large number of glandular hairs embedded in the viscous matter exuded by them. Each hair consists of a very short, multicellular stalk, capped by a large globular head. In specimens from later collections, however, and in many fresh ones, the ovary was covered by a ferruginous felt, and in this case the indumentum consisted largely of fascicled hairs, among which a few of the glandular hairs were interpolated. The former are stellate and shaggy, consisting of a short, multiseriate stalk to which is attached a number of uniseriate branches, pointing in all directions. These are a modification of the broom-shaped shaggy type drawn by Breitfeld, 1.c., Fig. 3, in which the arms are very regularly directed upwards. At the same time the branches were scarcely as spreading as shown in Fig. 6 on the same plate (both for Rhododendron Falconeri). The present hairs are, in fact, intermediate between the two figures. It is important to note that the glandular and fascicled hairs appear in very varying proportions on the ovary of R. Falconeri.

In the case of Rhododendron Hodgsoni the ovary possesses the fascicled type of hair only, imparting a whitish appearance and soft texture. 
The above have been treated at some length, not on account of their value as isolated facts, but for the reason that such anatomical details, where constant, are often of the greatest assistance in solving taxonomic problems, especially in the classification of specimens as prone to natural hybridization (even within the limit of one species) as the genus Rhododendron. In the case under consideration, the constancy of the character derived from the structure of the hairs seems to be sufficiently established by the examination of a large number of specimens, collected in different localities. Even if the amount of the tomentum varied, the type of hair remained the same for each species.

\section{SUMMARY.}

I. The orange-brown, velvety tomentum of the leaves of Rhododendron Falconeri, Hook. fo, is made up of peculiar funnel-shaped hairs, with branches one cell in thickness from the upper portion. That of $R$. Hodgsoni is more scaly, and the individual hairs are saucer-shaped, having a stalk at the centre of the convex surface. The broom-shaped, shaggy hair has not been observed on the leaves of $R$. Falconeri, as described by Breitfeld ; but a similar type occurs on the ovary of that species.

2. The tomentum of the ovary of $R$. Falconeri is extremely variable, thus accounting for the discrepancy existing between various descriptions. The ovary is covered by glandular and stellate hairs, these being found in very different proportions-in some cases either one or the other being entirely absent.

3. The types of hair described have been found to be constant in many specimens examined, even if the amount of tomentum varied. It is therefore to be concluded that they are of taxonomic assistance.

My thanks are due to Mr. L. A. Boodle for valuable help during the preparation of this note, and to Dr. O. Stapf, under whose direction the work has been carried out. 


\section{$2 \mathrm{BHL}$ Biodiversity Heritage Library}

Jesson, Enid M. 1915. "On the hairs of the tomentum and ovary in Rhododendron falconeri, Hook. f., and Rhododendron hodgsoni, Hook. f." Annals of botany 29, 635-638.

https://doi.org/10.1093/oxfordjournals.aob.a089572.

View This Item Online: https://www.biodiversitylibrary.org/item/243629

DOI: https://doi.org/10.1093/oxfordjournals.aob.a089572

Permalink: https://www.biodiversitylibrary.org/partpdf/320089

\section{Holding Institution}

Smithsonian Libraries

\section{Sponsored by}

Biodiversity Heritage Library

\section{Copyright \& Reuse}

Copyright Status: Not in copyright. The BHL knows of no copyright restrictions on this item.

This document was created from content at the Biodiversity Heritage Library, the world's largest open access digital library for biodiversity literature and archives. Visit BHL at https://www.biodiversitylibrary.org. 